УДК 32.019.51

\title{
СИМВОЛИЧЕСКАЯ РЕПРЕЗЕНТАЦИЯ СОТРУ ДНИЧЕСТВА МЕЖДУ РЕСПУБЛИКОЙ ИНДИЯ И КИТАЙСКОЙ НАРОДНОЙ РЕСПУБЛИКОЙ В СМК
}

\author{
Шабалин Кирилл Константинович \\ ФГАОУ ВО «Дальневосточный федеральный университет»
}

\begin{abstract}
Аннотация: В статье изучается символическая репрезентация кооперации между Индией и КНР в период с 2017 по 2019 гг. При помощи контент-анализа автор выбрал новостные статьи, авторы которых использовали культурные коды для репрезентации сино-индийской кооперации. В ходе анализа было продемонстрировано вмешательство китайского правительства в содержание статьи. Также была сформулирована разница в использовании метафор индийскими и китайскими журналистами.
\end{abstract}

Ключевые слова: Индия, Китай, репрезентация, концепт-анализ, политический дискурс.

\section{SYMBOLIC REPRESENTATION OF COOPERATION BETWEEN THE REPUBLIC OF INDIA AND THE PEOPLE'S REPUBLIC OF CHINA IN THE MEDIA}

\section{Shabalin Kirill Konstantinovich}

\begin{abstract}
The article examines the symbolic representation of cooperation between the Republic of India and the People's Republic of China in the period from 2017 to 2019. The author of the article used content analysis to select news articles whose authors had used cultural codes to represent Sino-Indian cooperation. The analysis demonstrated the Chinese government's interference in the content of an article. The author pointed out the difference in the use of metaphors by Indian and Chinese journalists.
\end{abstract}

Key words: India, China, representation, content analysis, political discourse. 
Сино-индийские отношения в течение последних пяти лет сложно назвать стабильными. Страны пережили дефицит взаимного доверия, переросший в пограничное противостояние в районе Доклам в 2017 г., выработали новую стратегию сотрудничества для восстановления подорванных отношений и вновь оказались на огневых позициях. Происходившие события активно освещались в средствах массовой коммуникации, которые, в свою очередь, были вынуждены подстраивать свою риторику в соответствии с действиями и намерениями правительств.

Цель работы заключалась в определении использования символической репрезентации для описания сотрудничества между Республикой Индия и КНР в англоязычных СМК с 2017 по 2019 гг. Данный период выбран по причине заметного улучшения сино-индийских отношений, что отразилось на содержании публикуемых материалов.

Для осуществления поставленной цели были выполнены следующие задачи:

1. проведение контент-анализа материалов СМК за 2017-2019 гг. с целью поиска символов, используемых политиками и журналистами обеих стран;

2. сопоставление символических репрезентаций кооперации в различных изданиях;

3. формулирование особенностей использования выбранных репрезентаций.

Для проведения исследования был выбран метод контент-анализа: статистический подсчет выбранных элементов текста [1, с. 92]. Контентанализ позволяет выявить влияние контроля на содержание и влияние содержания на аудиторию. Общественное мнение читателей прессы формируется при помощи многих инструментов, одним из которых является репрезентация. Репрезентации в СМК создают копию реальности, не имеющей настоящего оригинала, и транслируют этот образ в массы. Использование символических репрезентаций в политическом дискурсе привносит культурные контексты и коннотации, оказывающие ещё большее влияние на восприятие реальности аудиторией.

Индийская пресса отличается от китайской по нескольким критериям, ключевыми из которых являются свобода слова и отсутствие официальной государственной цензуры. В 1972 г. Капила Вацяян в докладе, подготовленном для ЮНЕСКО, отмечал, что все печатные издания Индии 
управляются частными предприятиями [2, с. 82]. В свою очередь, законодательство КНР о СМИ предусматривает нормы по ограничению прессы, цензуре и прочим формам контроля над содержанием, что приводит к подчинению издательств партийно-государственному контролю. Поэтому можно сделать допущение о влиянии китайского правительства на сознание граждан при помощи контроля медиадискурса.

Для анализа выбраны статьи из индийских и китайских печатных новостных порталов, публикуемых на английским языке, а именно «The Times of India», «China Daily», «Global Times». Данные предпочтения основываются на читаемости источников. Согласно отчету The Reuters Institute for the Study of Journalism, положение индийской прессы в Интернете вызывает сомнения, поэтому следует в первую очередь доверять количеству печатных копий. В 2019 г. тираж «The Times of India» составил более 5 млн. экземпляров [3], что сделало её самой большой печатной ежедневной газетой на английском языке в мире, и позволил удержать 3-ю позицию среди всех индийских печатных изданий. Согласно последнему доступному Indian Readership Survey, проведенному в 2019 г., 4 млн. граждан Индии регулярно следят за обновлениями «The Times of India» [4]. С другой стороны, независимые статистические данные по китайским СМК отсутствуют в открытом доступе, однако официальные страницы издательств предоставляют следующую информацию: на сайт англоязычный «China Daily» ежедневно заходит до 200,000 человек [5], a «Global Times» признается главной китайской газетой на английском языке [6].

При помощи метода сплошной выборки было отобрано по 60 статей от каждого новостного издания, которые стали основой проведенного исследования. Также соблюдалась тематическая доминанта материалов сино-индийский политический дискурс. Из выбранных 180 статей авторы только девяти использовали культурные коды для репрезентации синоиндийской кооперации. Индийские журналисты обращались к метафорическому описанию кооперации в двух статьях, а их китайские коллеги в семи.

Политики КНР прибегают к использованию метафорических сравнений для описания международных отношений. В одной из статей «China Daily» был опубликован комментарий Си Цзиньпина о китайско-индийском сотрудничестве. Председатель КНР сравнивал сотрудничество стран с реками Янцзы и Ганг, которые «никогда не прекращают течь и всегда движутся 
вперёд» [7]. Употребленная метафора имеет двоякое толкование: с одной стороны, индо-китайские отношения сравниваются с великими реками, которые по преданиям обеих стран зародились на небесах, следовательно их сотрудничество также предначертано свыше. С другой стороны, Китай активно использует Янцзы для налаживания экономической инициативы «Один пояс и один путь», к которой скептически относится индийская сторона. Такая интерпретация артикулирует экономические интересы КНР в Азии и предлагает Индии изменить свою позицию.

Китайские репортеры активно используют иллюстрации в газетах для репрезентации китайско-индийские отношений. Они отождествляют Индию со слоном, а Китай - с пандой $[8 ; 9 ; 10 ; 11 ; 12]$. Выбор таких образов не случаен: панда в китайской дипломатии - символ «soft power», приносящий мир и добрососедство; слон в индийской политической традиции означает стабильность и мудрость $[13,21]$.

Однако данное отождествление не поддерживают журналисты «Times of India». Они публикуют материал, посвященный решению инцидента в регионе Доклама, и сравнивают сино-индийские отношения с танцем слона и дракона [14]. Более того, индийские СМК, цитируя представителя министерства обороны КНР полковника У Цянь, пишут: «если дракон и слон танцуют совместно, то они оба выиграют и помогут азиатскому процветанию» [15]. Репрезентация КНР через образ дракона обладает ярко-выраженной агрессивной коннотацией, которую стараются избегать политики. Стоит отметить, что цитирование данной фразы не было найдено в китайских СМК. Из этого можно сделать вывод о том, что китайская пресса репрезентирует «новые» индо-китайские отношения только с позиции «мягкой силы» в то время, как правительство продолжает демонстрировать свои военные наклонности, которые отображаются на страницах индийских газет.

Китайские СМК использовали менее очевидный символ экономического сотрудничества - чай. «China Daily» опубликовала материал: «Xi's tea diplomacy» [16], посвященный международной дипломатии Си Цзиньпина. В статье было процитировано заявление председателя КНР о экономических и культурных отношениях между Индией и Китаем, которые отразились на схожести цивилизационных традиций.

На основании изложенного выше можно сделать вывод, что китайская пресса чаще использует символическую репрезентацию для описания сотрудничества между КНР и Республикой Индия. Данная тенденция может 
быть объяснена активным вмешательством правительства в публикуемый контент и стремление сформировать желаемый образ при помощи медиа. Влияние государственной идеологии на контент заметно при анализе метафор, используемых журналистами: слон и панда на страницах китайских газет, слон и дракон в индийской прессе. Получается, китайские СМИ демонстрируют дипломатию Пекина, основанную на мирном сотрудничестве, однако индийские издания склонны видеть в своем партнере агрессора.

\section{Список литературы}

1. Тичер, С. Мейер, М. Водак, Р. Веттер, Е. Методы анализа текста и дискурса / Пер. с англ. - Х.: Изд-во Гуманитарный центр. 2009. - 356 с.

2. Vatsyayan, K. M. Some aspects of cultural policies in India / by Kapila Malik Vatsyayan. - Paris: Unesco. Creation Date, - 1972. - 105 p.

3. Highest Circulated Daily Newspapers (languages wise) [Electronic resource] // Audit Bureau of Circulation. - Mode of access: http://www.auditbureau.org/files/JD\%202019\%20Highest\%20Circulated\%20(langu age $\% 20$ wise).pdf.

4. Indian Readership Survey Data Usage // Media Research Users Council India. - Mode of access: https://mruc.net/irs-data-usage\#pid=4.

5. About China Daily // China Daily. - Mode of access: https://www.chinadaily.com.cn/english/static/aboutchinadaily.html.

6. About the Global Times // Global Times. - Mode of access: https://www.globaltimes.cn/about-us/.

7. Baijie, A. Strong China-India ties hailed // China Daily. 2018. URL: http://www.chinadaily.com.cn/a/201804/28/WS5ae3768fa3105cdcf651b08b.html/

8. Minwang, L. Trump's policies bring Beijing, Delhi closer together // Global Times. 2018. URL: http://www.globaltimes.cn/content/1099296.shtml.

9. Sanwal, M. Neighbors move toward 'Asian Century' // China Daily. 2018. URL: http://africa.chinadaily.com.cn/a/201804/28/WS5ae3ad18a3105cdcf651b0 c0.html.

10. Swaran, S. China and India see upswing in relations // China Daily. 2018. URL: $\quad$ http://usa.chinadaily.com.cn/a/201804/24/WS5ade6122a3105cdcf651a 057.html.

11. Xingchun, L. Informal Xi-Modi meeting heralds new chapter in SinoIndian relations // Global Times. URL: http://www.globaltimes.cn/content/ 1099826.shtml. 
12. Xingchum, L. SCO nurtures Sino-Indian relations // Global Times. 2018. URL: http://www.globaltimes.cn/content/1106446.shtml.

13. Борзова, Е.П. Культура и политические системы стран Востока: учебник для вузов / Е.П. Борзова, И.И. Бурдукова. - М.: Издательство Юрайт, 2008. — 353 с.

14. Dasgupta, S. Dragon \& Elephant can dance together: China foreign mantri // Times of India. 2017. URL: https://timesofindia.indiatimes.com/india/ dragon-elephant-can-dance-together-china-foreign-mantri/articleshow/ 62030785.cms.

15. India, China in talks to establish hotline between defense ministries: Beijing // Times of India. 2018. URL: https://timesofindia.indiatimes.com/ world/china/india-china-in-talks-to-establish-hotline-between-defence-ministriesbeijing/articleshow/65608509.cms.

16. Jie, Y. Xi's tea diplomacy // China Daily. 2018. URL: http://www.chinadaily.com.cn/a/201807/11/WS5b45336ba3103349141e1f88_3.htm 